\title{
Modeling of Hydrogen Infrastructure for Fuel Cell Applications and Its Impact on Hydrogen Economic Era, Case Study in Semarang
}

\author{
Bayu Murti ${ }^{1, a)} \quad$ Sulistyo $^{1,2)} \quad$ Jaka Aminata ${ }^{1,3)}$ \\ 1.Master Program of Energy, School of Postgraduate Studies, Diponegoro University, Semarang, Indonesia \\ 2.Department of Mechanical Engineering, Faculty of Engineering, Diponegoro University, Semarang, Indonesia \\ 3.Department of IESP, Faculty of Economic and Bisnis, Diponegoro University, Semarang, Indonesia
}

\begin{abstract}
The current global trend is a shift in the use of fossil energy to hydrogen, known as the "hydrogen economy". At present transportation (automotive) is looking for alternative fuels as a substitute for fuel oil. In addition to using electricity as a driving force, hydrogen fuel is used as one of the fuels which can also be considered an option. This study seeks to determine the profile of energy consumption in Semarang district starting from the transportation to a certain year. The output of this research is about hydrogen infrastructure and making possible steps for a decission by knowing the profile of energy consumption in Semarang. Finally it will be known the potential of hydrogen infrastructure development which can become a guideline in determining the right policy in carrying out hydrogen infrastructure development in Semarang. The capacity of hydrogen production in Semarang is approximately $1,000 \mathrm{~m} 3$ / hour. The production breakdown per day is : $550 \mathrm{~m} 3$ / hour $\mathrm{x} 24=13,200 \mathrm{~m} 3$. It can be maximized the production of hydrogen for 360 days per year is $4,752,000 \mathrm{~m} 3$. The prediction of the hydrogen needs of 2020 in Semarang is 1,955,780 m3. Thus the production of hydrogen in Semarang can be fulfilled.
\end{abstract}

Keywords : hydogen fuel, oil fuel, production, transportation, Semarang

DOI: $10.7176 /$ JETP/10-3-04

Publication date:July $31^{\text {st }} 2020$

\section{INTRODUCTION}

Background research because air pollution has worsened in major cities around the world, so the use of car transportation must be limited and measures introduced to encourage clean vehicles[1]. The transportation sector is a major contributor to the emergence of global warming around $20 \%$ of greenhouse gas emissions caused by the transportation sector [2]. Hydrogen is an energy storage medium for electricity produced from renewable energy sources that makes important connections in the sustainable and emission-free energy chain from start to finish. Unlike fossil energy, hydrogen will not run out because hydrogen is the most common element found in nature. Hydrogen can be used both to produce electricity and as a fuel which makes it very suitable for stationary and mobile applications [1]. The current global trend is a shift in the use of fossil energy to hydrogen, known as the "hydrogen economy" [1]. One key to expanding alternative energy is to produce and introduce vehicles driven by energy sources other than petroleum fuels, such as hydrogen gas, so that each energy source is converted into electrical energy to drive a vehicle. Developing alternative energy diversification at the consumer level will prevent price increases and dependence on one fuel can be reduced [3].

\section{Basic theory}

Fuel cells are electrochemical cells that are similar to batteries, the difference is that the reactants consumed by fuel cells can be replenished continuously. Fuel cells produce electricity from outside hydrogen and oxygen supplies. Fuel cells are different from batteries where electricity is produced from internal energy. The electrodes in the battery react and change when the battery is charged or discharged, while the fuel cell electrode is catalytic and relatively stable[4]. Hydrogen needs infrastructure for distribution. [5].

\section{RESEARCH METHODOLOGI}

Case study was taken in Semarang. Semarang is also known as one of the metropolitan cities in Indonesia, where traffic congestion has always been a major problem in metropolitan cities. Based on data from DPAAD Semarang in 2014, the number of vehicles in Semarang reached 1,305,636. The number of vehicles in Semarang has also caused traffic jams in Semarang. The most prominent impact of the increasing number of vehicles in Semarang is increased air pollution.

\section{RESULTS AND DISCUSSION}

In 2014 , energy consumption $(\mathrm{Gj})$ in Semarang was calculated by the calculation below. We can see the calorie equation for joules can be written as:

$$
1 \mathrm{j}=0,2388 \mathrm{cal}
$$




$$
\begin{gathered}
1 \mathrm{Kcal}=1.000 \mathrm{cal} \\
1 \mathrm{Kcal}=1.000 \times 4,186 \text { joule } \\
1 \mathrm{Kcal}=4,186 \mathrm{Kj}
\end{gathered}
$$

The calculation of energy in $\mathrm{Gj}$ in Semarang can be written as:

\section{Diesel fuel energy in 1 year}

$$
1 \text { liter of diesel fuel }=10,546 \mathrm{kcal}
$$

1 liter of diesel fuel $=44,145 \mathrm{kj} /$ liter

In Semarang, diesel fuel consumption within 1 year of 2014 was $=187,495 \mathrm{kl}$ (Pertamina source).

Diesel fuel energy in 1 year is :

$$
\begin{aligned}
& \text { diesel fuel energy in } 1 \text { year }=187,495 \mathrm{kl} \mathrm{x} 44,145 \mathrm{Kj} / \text { liter } \\
& \text { diesel fuel energy in } 1 \text { year }=8,276,966,775 \mathrm{Kj} \\
& \text { diesel fuel energy in } 1 \text { year }=8,276.966775 \mathrm{Gj}
\end{aligned}
$$

\section{Premium energy in 1 year}

$$
\begin{gathered}
1 \text { liter of Premium }=10.509 \mathrm{Kcal} \\
1 \text { liter of Premium }=43,990 \mathrm{Kj} / \text { liter }
\end{gathered}
$$

In Semarang the consumption of premium within 1 year in 2014 was $=349,448 \mathrm{kl}$ Premium.

Premium energy in 1 year is:

$$
\begin{gathered}
\text { Premium energy in } 1 \text { year }=349,448 \mathrm{kl} \mathrm{x} 43,990 \mathrm{Kj} / \text { liter } \\
\text { Premium energy in } 1 \text { year }=15,372,217,520 \mathrm{Kj} \\
\text { Premium energy in } 1 \text { year }=15,372,217520 \mathrm{Gj}
\end{gathered}
$$

Pertamax energy in 1 year

$$
1 \text { liter Pertamax }=10,622 \mathrm{Kcal}
$$

1 liter Pertamax $=44,463 \mathrm{Kj} /$ liter

In Semarang, the consumption of Pertamax within 1 year of 2014 was $=16,804$ kilo liters of Pertamax. Pertamax energy in 1 year is:

$$
\begin{gathered}
\text { Pertamax energy in } 1 \text { year }=16,804 \mathrm{kl} x 44,463 \mathrm{Kj} / \text { liter } \\
\text { Pertamax energy in } 1 \text { year }=747,156,252 \mathrm{Kj} \\
\text { Pertamax energy in } 1 \text { year }=747,156 \mathrm{Gj}
\end{gathered}
$$

Table 1 below shows a simulation of the rate of growth of fuel consumption in Semarang according to Public Relations of PT. Pertamina Marketing Operation Region (MOR) IV Central Java-DIY Jl. Pemuda No.114 is $0.3 \%$ per year, so the consumption of fuel oil in Semarang in 2014 to 2024 can be predicted using LEAP software. In 2014 , diesel fuel energy in 1 year $=8,276.966775 \mathrm{Gj}$. Premium energy in 1 year $=15,372,217520 \mathrm{Gj}$. Pertamax energy in 1 year $=747,156 \mathrm{Gj}$. Total energy is obtained from the sum of the total diesel fuel, premium and Pertamax energy. Solar energy in 1 year $=8,276.966775 \mathrm{Gj}$. Premium energy in 1 year $=15,372,217520 \mathrm{Gj}$. Pertamax energy in 1 year $=747,156 \mathrm{Gj}$. After adding up the results were 24,396 Gj in 2014 .

Table 1. Relationship between Energy needs in Semarang throughout the year and GJ units.

\begin{tabular}{ll}
\hline Year & fuel oil $(\mathbf{G j})$ \\
\hline 2014 & $24.396,0$ \\
2016 & $24.542,6$ \\
2018 & $24.690,1$ \\
2020 & $24.838,4$ \\
2022 & $24.987,7$ \\
2024 & $25.137,8$ \\
\hline
\end{tabular}

\section{Infrastructure that might be built in Semarang.}

Design data for hydrogen production from Samator Kec. Bambe, Kab. Gresik by Bp. Ponari, Hydrogen Plant division, and Bp. Sampoerno, as the leader are as follows:

1. Design capacity for hydrogen production in the samator with a cap. Design plant $1,000 \mathrm{~m} 3 /$ hour. With a volume of $1 \mathrm{~m} 3=0.0810 \mathrm{~kg}$, it will produce $81 \mathrm{~kg} /$ hour. Production breakdown per day: $550 \mathrm{~m} 3 /$ hour x 24 hours $=13,200 \mathrm{~m} 3$ or $1,069,2 \mathrm{~kg}$

2. General selling prices Estimated between Rp. $62,000 / \mathrm{m} 3$

3. H2 tube trailer with Fill capacity @ 4,000 m3 with working pressure of $200 \mathrm{~kg} / \mathrm{cm} 2$.

\section{Prediction If the vehicle is directed to hydrogen fuel}

Prediction If the vehicle is directed to hydrogen fuel with the calculation of a hydrogen heating value (HHV) of 
12.7 MJ / m3 [6]. can be written as:

$$
\begin{aligned}
& 12.7 \mathrm{MJ} / \mathrm{m} 3=12,700 \mathrm{KJ} / \mathrm{m} 3 \\
& 1 \mathrm{~m} 3=12.7 \mathrm{MJ}=0.0127 \mathrm{GJ}
\end{aligned}
$$

With mathematical equations, the calculation will be obtained in Table 2 . The relationship between energy needs in Semarang throughout the year is changed to $\mathrm{m} 3$, with $1 \mathrm{~m} 3=12.7 \mathrm{MJ}=0.0127$ GJ. can be written as table 2 below.

Table 2. Energy demand conversion in Semarang throughout the year

\begin{tabular}{|l|r|r|r|r|r|r|r|r|r|r|}
\hline & 2014 & 2015 & 2016 & 2017 & 2018 & 2019 & 2020 & 2021 & 2022 \\
\hline Gj & $24.396,00$ & $24.469,20$ & $24.542,60$ & $24.616,20$ & $24.690,10$ & $24.764,10$ & $24.838,40$ & $24.912,90$ & $24.987,70$ \\
\hline m3 & 1920945 & 1926709 & 1932488 & 1938283 & 1944102 & 1949929 & 1955780 & 1961646 & 1967535 \\
\hline
\end{tabular}

\section{Prediction of the amount of hydrogen used in Semarang}

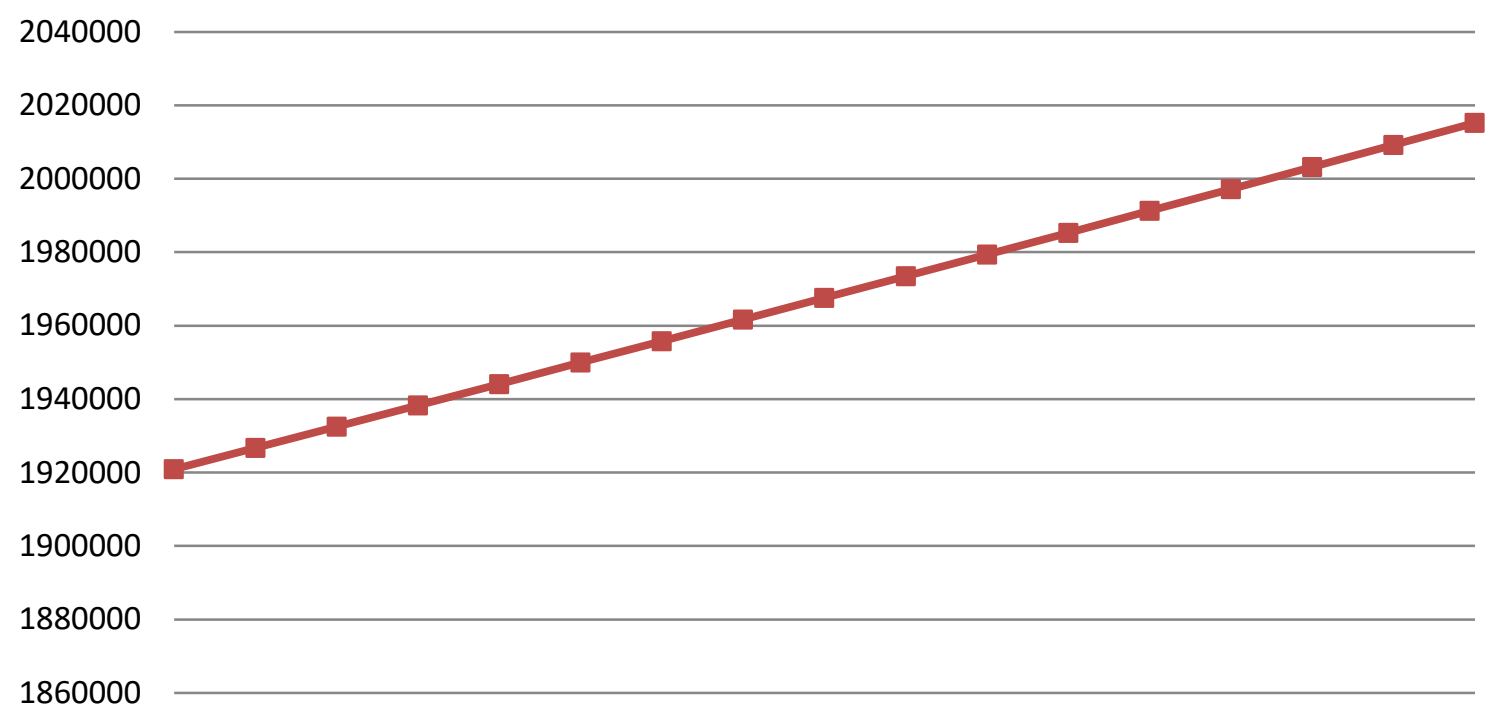

20142015201620172018201920202021202220232024202520262027202820292030 - Hidrogen

Figure 1. Prediction of the amount of hydrogen used in Semarang. The $x$-axis writes the amount of hydrogen needed per $\mathrm{m} 3$, and the $y$-axis writes the year.

Table 3. Predictions of total hydrogen usage in Semarang.

\begin{tabular}{cc}
\hline Year & Hydrogen $(\mathrm{m} 3)$ \\
\hline 2014 & $\mathbf{1 . 9 2 0 . 9 4 4 , 8 8 2}$ \\
2016 & $1.932 .488,189$ \\
2018 & $1.944 .102,362$ \\
2020 & $1.955 .779,528$ \\
2022 & $1.967 .535,433$ \\
2024 & $1.979 .354,331$ \\
\hline
\end{tabular}

The design capacity of hydrogen production in Samator is $1,000 \mathrm{~m} 3$ / hour. Production breakdown per day: $550 \mathrm{~m} 3$ / hour x 24 hours $=13,200 \mathrm{~m} 3$. It can be maximized the production of hydrogen for 360 days per year is $4,752,000 \mathrm{~m} 3$. In 2020 based on table 2, hydrogen demand prediction in Semarang $=1,955,780 \mathrm{~m} 3$.

\section{Comparison of fuel and hydrogen costs}

In 2014, diesel fuel consumption in Semarang was $=187,495 \mathrm{kl}$ of diesel fuel. In 2014, the use of premium in Semarang was 349,448 kl Premium. In 2014, the use of Pertamax in Semarang was =16,804 kl Pertamax, then the total cost is as follows:

1. Diesel fuel $187.495 \mathrm{Kl}$ x Rp. 9,500 / 1 = Rp. 1,781,202,500,000

2. Premium 349,448 Kl x Rp. 6,550 / 1 = Rp. 2,288,884,400,000

3. Pertamax 16.804K1 x Rp. 9,200 / 1 = Rp. 154,596,800

The total fuel costs in Semarang, if all added up are as follows:

Rp. $1,781,202,500,000+$ Rp. $2,288,884,400,000+$ Rp. $154,596,800=$ Rp. $4,070,241,496,800$ 
From table 1, in 2020, fuel prediction in Semarang is $24,838 \mathrm{Gj}$.

The total fuel costs of Semarang in 2014 divided by the total energy in 2014 are as follows:

$$
\text { Rp. 4,070,241,496,800 divided by 24,396 Gj = Rp. 166,840,527.- }
$$

The price of fuel per $1 \mathrm{Gj}=\mathrm{Rp}$. 166,840,527.-

The total cost of fuel in 2020 is the price of fuel per $1 \mathrm{Gj}$ multiplied by the total energy in 2020 with the following equation:

$$
\text { Rp. } 166,840,527 \text { x 24,838 Gj= Rp. 4,143,985,009,626.- }
$$

The price of $1 \mathrm{Gj}$ of hydrogen can be calculated by the calculation below.

$$
\begin{aligned}
& 1 \mathrm{~m} 3 \text { of hydrogen }=0.0127 \mathrm{Gj} \\
& 1 \mathrm{Gj}=1 / 0.0127=78.740 \mathrm{~m} 3
\end{aligned}
$$

Price of $1 \mathrm{Gj}=78.740 \mathrm{~m} 3 \times \mathrm{Rp} .62,000$

$$
\text { Price of } 1 \mathrm{Gj}=\text { Rp. } 4,881,880
$$

From table 1, the total hydrogen costs obtained in the city of Semarang in 2020 are:

Price of $1 \mathrm{Gj}$ hydrogen $\mathrm{x}$ total $\mathrm{Gj}$ hydrogen

$$
\text { 24,838Gj x Rp. 4,881,880 = Rp. 121,256,135,440 }
$$

\section{CONCLUSION}

From this research it can be concluded that: 1 . The design capacity of hydrogen production in samators is 1,000 $\mathrm{m} 3$ / hour. Details of production per day: $550 \mathrm{~m} 3$ / hour x 24 hours $=13,200 \mathrm{~m} 3$. Hydrogen production can be maximized for 360 days per year so total hydrogen production in Samator is $4,752,000 \mathrm{~m} 3$. In 2020, predicted hydrogen demand in Semarang $=1,955,780 \mathrm{~m} 3$. The need for hydrogen if all vehicles are diverted with hydrogen by 2020 can be fulfilled. 2. predicted total fuel costs in 2020: Rp. 166,840,527 x 24,838 $\mathrm{Gj}=\mathrm{Rp}$. $4,143,985,009,626$. - 3. Predictable total hydrogen costs in Semarang in $2020=1 \mathrm{Gj}$ price of hydrogen $\mathrm{x}$ total $\mathrm{Gj}$ of hydrogen. $24,838 \mathrm{Gj}$ x Rp. 4,881,880 = Rp. 121,256,135,440

\section{Acknowledgments}

The author gratefully acknowledge to Master Program of Energy, School of Postgraduate Studies, Diponegoro University, Semarang, Indonesia.

\section{References}

[1] Rosyid, Oo Abdul, Infrastruktur hidrogen untuk aplikasi fuel cell dalam era ekonomi hidrogen, Balai Besar Teknologi Energi (B2TE-BPPT), Kawasan Puspiptek Serpong, Tangerang, 2009.

[2] The World Bank, Low-emission transport, (http://www.worldbank.org/en/ topic/transport/brief/lowemission-transport;. 2014.

[3] Liun Edwaren, Analisis Keekonomian Bahan Bakar Produk Nabati dan Hidrogen Nuklir. Pusat Pengembangan Energi Nuklir (PPEN) -BATAN, Jakarta, 2011.

[4] Matthew, Mench M., Fuel Cell Engines, Jhon Wiley \& Sons, Inc., Hoboken, New Jersey. United States of America, 2008.

[5] Isdiriyani Nurdin, http:// www.energi.lipi.go.id/, 2005.

[6] Fung Michele, fact, https://hypertextbook.com/ facts/2005/MichelleFung .shtml, 2005. 